\title{
Theories of Constitutional Interpretation
}

Modern democracy invites us to replace the notion of a regime founded upon laws, of a legitimate power, by the notion of a regime founded upon the legitimacy of a debate as to what is legitimate and what is illegitimate-a debate which is necessarily without any guarantor and without any end.

-Claude Lefort ${ }^{1}$

In 1979 ERnest Chambers was a barber who had for nine years represented a predominantly black district of Omaha in the Nebraska Unicameral Legislature. He had been brought up in "a religious strait-jacket" in the fundamentalist Church of God and Christ, but as he had grown older he had come to renounce Christianity and all belief in God. Consequently he was uncomfortable when the chaplain hired by the legislature opened each session with prayer. In fact he felt compelled to leave the legislative chamber, so that he and the chaplain were "almost in a race to see whether" the chaplain could "get to the front before" Chambers could "get out the back door."2

The chaplain of the Nebraska Legislature during that time was Robert E. Palmer, a Presbyterian clergyman who had ministered to the legislators since 1965. His prayers were short, almost perfunctory. He strove to make them nonsectarian, to reflect "just civil religion in America," which he understood to consist of "the Judeo-Christian tradition," the "kind of religious expressions that are common to the vast, overwhelming majority of most all Americans." He viewed the purpose of his prayers to be the provision of "an opportunity for Senators to be drawn closer to their understanding of God as they understand God, in order that the divine wisdom might be theirs as they conduct their business for the day." And so he would, for example, pray "in the name of Jesus-our Friend, our Saviour, our Example, our Guide," and he would "ask" that the Senators come to realize that "they are part of the team working together to win the game for the benefit of the people of this state."

Chambers attempted to convince his colleagues to end the practice of legislative prayer. When they refused, he took the characteristically American step of filing suit in federal court. His claim was elegantly simple: the payment of a state salary to the minister of a single Christian denomination for fourteen years for the purpose of offering official prayers to the state legislature was a violation of the Establishment Clause of the First Amendment to the United States Constitution. That clause provides: "Congress shall make no law respecting an establishment of religion." 4 
The trial court held that while the payment of the chaplain's salary violated the Establishment Clause, the observance of legislative prayer did not. ${ }^{5}$ The appellate court went even further and declared that the whole "prayer practice" was unconstitutional. ${ }^{6}$ The case was then accepted for decision by the United States Supreme Court, by which time the concrete concerns of Ernest Chambers and Robert Palmer had dwindled to little or no moment. Chambers's lawsuit had become merely a medium through which the Court could ponder the legal meaning for the entire nation of the Establishment Clause. The methods by which the Court ascertains this constitutional meaning are of the utmost legal and political importance. Ernest Chambers's lawsuit would prove to be the occasion for an unusually clear and dramatic display of these methods.

\section{I}

Sometimes, although rarely, the words of the Constitution appear to speak for themselves. In such circumstances the Constitution does not seem to require interpretation. Article I, Section 3, Clause 1 of the Constitution, for example, states that "the Senate of the United States shall be composed of two Senators from each State." If a third California Senator should one day present herself for accreditation in Washington, D.C., no court in the country would think twice before disapproving of the application. From a phenomenological point of view, there would be no question of "interpreting" the constitutional language, for its meaning and application would appear clear and obvious. ${ }^{7}$

The most famous expression of the experience of this clarity is by Justice Owen Roberts, who in 1936 wrote that the "judicial branch of the government has only one duty,- - to lay the article of the Constitution which is involved beside the statute which is challenged and to decide whether the latter squares with the former." In legal circles, this approach is sometimes characterized as a "plain meaning" or "textualist" theory of interpretation. Yet, strictly speaking, the approach is not a theory at all; it is instead a description of what happens when constitutional meaning is not problematic.

But if for any reason that meaning has become questionable, it is no help at all to instruct a judge to follow the "plain meaning" of the constitutional text. A meaning that has ceased to be plain cannot be made so by sheer force of will. ${ }^{9}$ In Chambers's lawsuit, for example, either the meaning of the Establishment Clause with respect to the issue of legislative prayer is "plain," or it is not. If the latter, the question of constitutional meaning cannot be resolved by staring harder at the ten words of the clause. What is required instead is a means of interpreting the text so as to mediate between the clause and its application. ${ }^{10}$

Because judges must be able to justify their decisions, they must also be able to justify the means of interpretation that they employ to reach those decisions, 
particularly if their choice affects the ultimate result or significance of a case. Judges must be able to explain why they have decided to interpret the Constitution through one set of inquiries rather than another. In legal (although not in philosophical or literary) parlance, judges require and must be able to articulate a "theory" of constitutional interpretation.

Any such theory of interpretation, however, must accommodate itself to the role of judicial review within American democracy. When a court sets aside a statute as unconstitutional, it in essence deems the statute invalid in the name of the Constitution. Courts have claimed the power to do this because, in the famous words of John Marshall in Marbury $v$. Madison, the decision that established the institution of judicial review, "it is emphatically the province and duty of the judicial department to say what the law is." 11 The implicit premise of this claim is that the Constitution is a form of "law," just like the law which courts ordinarily interpret and apply. Fidelity to law is a preeminent value in a nation that, as Marshall put it in Marbury, prides itself in being "a government of laws, and not of men." 12

But, as the force of Marshall's argument in Marbury also required him to acknowledge, the Constitution is something more than ordinary law; it is "the fundamental and paramount law of the nation." The Constitution is "fundamental" because it is the vehicle through which "the people . . establish, for their future government, such principles as, in their opinion, shall most conduce to their own happiness." The Constitution is therefore "the basis on which the whole American fabric has been erected." ${ }^{3}$ The question arises, therefore, why it should be the province and duty of the federal judiciary to discern in that "American fabric" the "principles" and "opinion" of "the people," when that judiciary is not elected by and hence structurally responsible to the people. Why shouldn't that task be allocated instead to the democratically elected branches of government, which are presumptively in closer contact with the popular mind?

This question, which is sometimes termed the "counter-majoritarian" difficulty, ${ }^{14}$ has proved durable enough to sustain the work of generations of constitutional scholars. The question makes a powerful political point. Judicial determinations of unconstitutionality nullify the actions of democratically elected branches of government. Such determinations are for all practical purposes final; often the only formal recourse is the cumbersome and impractical process of constitutional amendment. "Who are these nine Justices," one may well have asked the Court in 1857 after the Dred Scott decision, ${ }^{15}$ "so definitively to instruct the nation about the 'American fabric'?"

\section{II}

The United States Supreme Court voted 6 to 3 against Ernest Chambers. If one were simply to view the Constitution as ordinary law, this outcome 
would have been something of a surprise. The relevant precedents of the Court pointed unambiguously to the unconstitutionality of the practice of legislative prayer. As Justice William J. Brennan pointed out in his dissent, it is "obvious that, if the Court were to judge legislative prayer through the unsentimental eye of our settled doctrine, it would have to strike it down as a clear violation of the Establishment Clause." 16

In ordinary adjudication, courts follow the principle of stare decisis, which is to say that they follow the doctrinal rules laid down in controlling precedents. ${ }^{17}$ In American law, the principle constitutes a fundamental aspect of "the rule of law," 18 for it requires courts to decide cases on the basis of public and predictable rules, applied in an even-handed manner, upon which persons can rely in the conduct of their lives. ${ }^{19}$ In constitutional adjudication, "adherence to precedent can contribute to the important notion that the law is impersonal in character, that the Court believes itself to be following a 'law which binds [it] as well as the litigants." "20 The principle of stare decisis helps to ensure that our constitutional order retains the kind of stability and continuity that are prerequisite for institutional legitimacy.

If the Court in Ernest Chambers's case had followed the principle of stare decisis, it would have deemed controlling, as did the Court of Appeals below, ${ }^{21}$ the three-part doctrinal test laid down in Lemon $v$. Kurtzman: ${ }^{22}$

Every analysis in this area must begin with consideration of the cumulative criteria developed by the Court over many years. Three such tests may be gleaned from our cases. First, the statute must have a secular legislative purpose; second, its principal or primary effect must be one that neither advances nor inhibits religion; finally, the statute must not foster "an excessive government entanglement with religion."

The primary purpose of religious prayer cannot reasonably be deemed to be secular; nor can its principal effect be understood as anything other than enhancing religion. As for the potential for "excessive government entanglement with religion," it is apparent that official sponsorship of prayer necessarily entangles the state in decisions about which forms of prayer are appropriate or inappropriate. The word was passed to Reverend Palmer, for example, that Jewish senators in the Nebraska Legislature were offended by his many references to Christ. ${ }^{23}$ Eighty years before, when a state senator conveyed a similar message to the legislative chaplain of the State Senate of California, a local clergyman thundered that the senator's "words were those of an irreverent and godless man" and that his offense was a "crowning infamy." 24 The point of the "entanglements" prong of the Lemon rule is to ensure that the state not be embroiled in religious quarrels of this kind.

"In sum," as Justice Brennan remarked, "I have no doubt that, if any group of law students were asked to apply the principles of Lemon to the question of legislative prayer, they would nearly unanimously find the practice to be uncon- 
stitutional." 25 A fascinating aspect of the Chambers decision, however, is that the majority neither disagreed with this assessment, nor attempted to alter the Lemon doctrine. In fact it ignored Lemon altogether, making no effort whatever to justify its decision by reference to past precedents.

Instead the Court, in an opinion written by Chief Justice Warren Burger and joined by five other Justices, focused its analysis on the fact that the "opening of sessions of legislative and other deliberative bodies with prayer is deeply embedded in the history and tradition of this country." The Court noted that most States of the Union have traditionally opened their legislative sessions with prayer, and that Congress has continuously employed chaplains to offer legislative prayer since the eighteenth century. Indeed, on 22 September 1789, three days before Congress approved the language of the First Amendment (and the Establishment Clause) and sent it to the States for ratification, Congress enacted a statute providing for the payment of congressional chaplains. ${ }^{26}$

Although the Court conceded that "standing alone, historical patterns cannot justify contemporary violations of constitutional guarantees," it concluded that the evidence in Chambers's case was different, for it definitely established "not only . . . what the draftsmen intended the Establishment Clause to mean, but also . . . how they thought that Clause applied to the practice authorized by the First Congress-their actions reveal their intent." "Clearly," the Court concluded, "the men who wrote the First Amendment Religion Clauses did not view paid legislative chaplains and opening prayers as a violation of that Amendment." ${ }^{27}$

The premise of the majority's opinion is thus that the meaning of the Constitution is better ascertained through strong evidence of the intent of the Framers than through fidelity to past precedents and doctrine. The reason is apparently that the intent of the Framers best embodies those "principles" which the "people" desired to instantiate in their Constitution. In the eyes of the majority, therefore, it is more important that the Constitution be interpreted in a manner which accurately expresses these principles than that it be interpreted in a manner which remains faithful to the principle of stare decisis. ${ }^{28}$

The principle of stare decisis, moreover, is inconsistent with a quite different method of constitutional interpretation. William Brennan, in a dissent joined by one other Justice, also gave only cursory attention to the rules of Lemon. In fact he appeared to agree with the majority that "the path of formal doctrine . . . can only imperfectly capture the nature and importance of the issues at stake in this case." ${ }^{29}$ But rather than focusing on the intentions of the Framers of the First Amendment, Brennan offered instead an "account" of "the underlying function of the Establishment Clause" and of the relationship between that function and the practice of legislative prayer.

According to Brennan, the Establishment Clause embodies the twin principles of "separation between church and state" and "neutrality" as between diverse religions. These two principles, in turn, serve four purposes. They guarantee "the 
individual right to conscience" by ensuring that persons are not coerced to support (through taxes or otherwise) religious practices with which they disagree; they "keep the state from interfering in the essential autonomy of religious life"; "they prevent the trivialization and degradation of religion by too close an attachment to the organs of government"; and they "help assure that essentially religious issues, precisely because of their importance and sensitivity, not become the occasion for battle in the political arena." 30

Brennan convincingly demonstrated that Nebraska's authorization of legislative prayer was inconsistent with each of these four purposes. Indeed, as Brennan noted, the majority said "almost nothing contrary to" this functional analysis, relying instead almost entirely on evidence of the historical intent of the Framers. The majority ultimately differed from the dissent, therefore, neither on the application of doctrine nor on the function of the Establishment Clause, but rather on the relevance of evidence of original intent for constitutional interpretation.

Brennan explicitly rejected such evidence as definitive of constitutional meaning, arguing that "the Constitution is not a static document whose meaning on every detail is fixed for all time by the life experience of the Framers." He contended that the Constitution must be understood instead as "a document meant to last for the ages," the bearer of an "inherent adaptability" that could not be cabined by any "static and lifeless" meaning. His proposed analysis of the Establishment Clause's "underlying function" was meant to illustrate how courts could discern the contemporary significance of "the majestic generalities of the Bill of Rights." ${ }^{11}$ His dissent pictured the Constitution as a living, evolving entity, whose full meaning could be ascertained neither by doctrinal precedent nor by evidence of original intent. The dissent, therefore, was predicated upon yet a third form of constitutional interpretation.

The outcome of Ernest Chambers's lawsuit thus appears as a triangular structure, in which three distinct theories of interpretation compete for control of the Constitution. In one corner is a form of interpretation that strives to implement the Constitution through the articulation of explicit doctrinal rules. In a second corner is a form of interpretation that attempts to construe the Constitution to reflect the original intent of its Framers. In yet a third corner is a form of interpretation that reads the Constitution in a manner designed to express the deepest contemporary purposes of the people. Each of these three theories is immediately recognizable and familiar to those who practice constitutional adjudication.

\section{III}

The purpose of constitutional adjudication is to assess the constitutional validity of state actions, like the hiring of legislative chaplains. But courts 
can achieve this purpose only to the extent they have the authority to evaluate, in the name of the Constitution, the validity of otherwise perfectly legal state actions. Every act of constitutional interpretation invokes and depends upon this authority, and for this reason "constitutional interpretation is essentially about the sources of authority in American political life." 32 What in fact distinguishes the three theories of interpretation displayed in Chambers-theories that I shall respectively call "doctrinal," "historical," and "responsive" interpretation-is that each appeals to a different conception of constitutional authority.

The authority of law. There is, first, the authority of the Constitution as law. The Constitution controls state actions because the Constitution is the highest law, above all merely quotidian state activity. The concept of the "constitution as hard law, law written in virtually capital letters (LAW), law as meaning reliable law," has been termed "by far the most important idea of the Constitution." 33 Because "courts are the mere instruments of the law," 34 they are peculiarly fitted to interpret a Constitution whose authority lies in its character as law. It is therefore no accident that in Marbury Marshall appealed precisely to this image of constitutional authority in establishing the institution of judicial review.

If the Constitution predominates because it is law, its interpretation must be constrained by the values of the rule of law, which means that courts must construe it through a process of reasoning that is replicable, that remains fairly stable, and that is consistently applied. ${ }^{35}$ In American adjudication the principle of stare decisis has been an essential component of the rule of law. ${ }^{36}$ The principle is of particular importance on those occasions when constitutional adjudication involves vague textual referents (like "equal protection of the laws," or "due process of law"), with regard to which there is "only limited evidence of exactly how the Framers intended the [text] to apply." ${ }^{37}$ On these occasions the principle of stare decisis holds courts to a consistent and stable interpretation of Constitution.

Without such consistency and stability, it would be difficult to understand the Constitution as having any existence as law. Suppose, for example, that the Supreme Court were to decide one day in decision A that the practice of legislative prayer was constitutional, perhaps because in its view the Framers had so intended. Imagine that a month later the Court were to decide in decision B, without any reference to $\mathrm{A}$, that the practice was unconstitutional, perhaps because the Court's view of the Framers' intent had changed. And assume that one month later the Court were to determine in decision $\mathrm{C}$, without any reference to $\mathrm{A}$ or $\mathrm{B}$, that the practice was partially constitutional, perhaps because its reading of the historical evidence had once again altered. In such circumstances state legislators would simply not know what to do; they would have no rule of law by which to decide whether or not they could constitutionally hire legislative chaplains. $^{38}$ 
It is of course implausible to suppose that the Court would so swiftly and radically change its assessment of the historical evidence. But the question is whether this implausibility derives from the unequivocal state of the historical record, or rather from the Court's implicit obligation to remain faithful to its own prior determinations. Since historical evidence is often equivocal, particularly with respect to matters of contemporary constitutional moment, it is the latter obligation, I would suggest, that plays an important role in enabling courts to create stable and predictable rules upon which persons can rely in the arrangement of their lives and institutions. ${ }^{39}$ This obligation receives formal acknowledgement in the principle of stare decisis.

This means that the principle of stare decisis often underlies the capacity of constitutional adjudication to generate a system of constitutional law. Thus the Chambers decision creates a rule of constitutional law only because of the implicit commitment of the Court to act in the future in ways that are consistent with the Chambers holding. Put another way, the legal implications of Chambers depend upon the implicit and necessary expectation that the Court will in the future treat Chambers in a way that it declined in Chambers to treat Lemon. ${ }^{40}$

Of course the principle of stare decisis is an immensely flexible instrument, allowing courts to treat precedents on the one hand as the source of specific and binding formal rules, ${ }^{41}$ or on the other as an amorphous mass of material to be rendered consistent through the virtue of "integrity." ${ }^{2}$ What every application of the principle requires, however, is that a court focus its analysis on the doctrine which has emerged from relevant prior cases. The principle of stare decisis therefore creates a chain of cases, in which each decision is an interpretation of immediately prior decisions.

Construing the Constitution in a manner that is faithful to its authority as law thus leads to what I shall call "doctrinal" interpretation. The implication of doctrinal interpretation is that the actual text of the Constitution is remitted to one end of a growing line of precedents. Even if the very first judicial decision to interpret the Establishment Clause had concentrated its attention on the specific words of the Clause or the intentions of its Framers, the practice of doctrinal interpretation would require the second decision to focus chiefly on the meaning of the first decision, the third decision chiefly on the meaning of the second, and so forth. In this process the text of the Constitution recedes until, as one prominent commentator has put it, it comes to seem "rather like ... a remote ancestor who came over on the Mayflower." 43

The vast majority of constitutional decisions rely primarily upon doctrinal interpretation. Novices are often quite struck by the relative absence of the Constitution from constitutional opinions, which seem oriented instead toward specific doctrinal "tests," like the Lemon tests, derived from prior judicial decisions. But this should be no surprise if the most powerful justification for the Constitution's authority is that it is law, and the most defensible justification for 
judicial review is that it is the peculiar province and duty of the courts to expound the law.

The authority of consent. If doctrinal interpretation rests on the equation of constitutional authority with law, what I shall call "historical interpretation" rests instead on the equation of constitutional authority with consent. The story is simple and familiar. The Framers of the Constitution proposed a compact to limit the power of government; the people signified their agreement to that compact by their ratification of the Constitution, and that agreement is what gives the Constitution its authority. The interpretation of the Constitution should therefore be designed to give effect to the terms of that original act of agreement.

The story behind historical interpretation has enormous resonance in a liberal society like our own. It conceives of the Constitution as binding in the same way that a promise is binding, as a single voluntary act of willful self-regulation. In interpreting such a Constitution courts can portray themselves as merely the passive enforcers of the democratic will that "ordained and established" the Constitution. Thus, as former Attorney General Edwin Meese II I could observe, "A Jurisprudence of Original Intention . . reflects a deeply rooted commitment to the idea of democracy. The Constitution represents the consent of the governed to the structures and powers of the government. The Constitution is the fundamental will of the people; that is why it is the fundamental law." 44

Different variants of historical interpretation emphasize different forms of evidence as probative of that original exercise of "fundamental will." Thus for some commentators the constitutional "text" is a privileged form of evidence, because "the text is the intention of the authors or of the framers"; ${ }^{45}$ whereas for others the "relevant inquiry must focus on the public understanding of the language when the Constitution was developed." 46 By far the most common form of historical interpretation, and the one used by Chief Justice Burger in Chambers, regards the intentions of the Framers as the best evidence of the agreement represented by the Constitution. ${ }^{47}$

This form of historical interpretation has become quite controversial in recent years, in part because some members of the resurgent Right have attempted to use historical interpretation as a means of constricting the discretion of supposedly liberal judges. The notion is that judges will have less room to maneuver if they are bound to the specific factual intentions of the Framers. But this notion is a vulgar misinterpretation of the principles of historical interpretation, as is elegantly illustrated by an example suggested by Paul Freund. Article I, Section 8, Clause 14 of the Constitution gives to Congress the power "to make Rules for the Government and Regulation of the land and naval forces." It can be said with complete certainty that no one in the eighteenth century had the intent to endow Congress with the power to make rules for the regulation of an 
air force. But no reasonable person would conclude from this undisputed fact that Congress does not now have this power. ${ }^{48}$ This is because the intent behind the Clause would naturally be understood as giving Congress the power to regulate the "military" or the "armed forces," or some other such general concept.

The point of Freund's example is that the intent of the Framers cannot be understood as the kind of simple historical fact that resists interpretation. It must instead be conceived as a purpose which can be characterized in terms that are more or less general..$^{49}$ Once this move is taken, however, historical interpretation assumes a flexibility inimical to the political purposes of the Right.

Historical interpretation is a rather uncommon phenomenon in modern constitutional adjudication. In part this may be due to the logical and evidentiary difficulties involved in the effort to unearth historical intentions. It is hard enough to ascertain the intentions of a living individual. It is harder still to determine the intention of a group of living individuals, like a legislature or a Congress. The difficulty is compounded when the group of individuals is two centuries remote in time and the evidence of their thoughts and purposes is scattered, fragmentary, ambiguous, and conflicting. And the task is made almost impossible when the relevant intentions pertain to questions which in all probability never occurred to that group of individuals and which are meaningful only in light of circumstances that would to them be inconceivable.

It is the rare case indeed that, like Chambers, seems to present strong evidence of original intention on the precise question to be adjudicated. Even in such a case, as Brennan points out in his dissent, the logic of democratic consent requires that the intentions of those who ratified the Constitution be controlling, rather than the intentions of those who merely proposed constitutional language for popular adoption. ${ }^{50}$ And, as Brennan cheerfully notes, "We know practically nothing about what went on in the state legislatures' during the process of ratifying the Bill of Rights." ${ }^{11}$

It is important to understand, however, that these obstacles to historical interpretation, while formidable, are not necessarily fatal. First, in any given case the available historical evidence of intent may be more or less compelling. Second, the nature of the evidence that will count as probative of intent may itself be entirely a matter of "generally accepted conventions," ${ }^{52}$ and hence shaped in a manner designed to ease the course of historical inquiry. For example, historical interpretation now focuses on the intent of the Constitution's framers, rather than of its ratifiers, because the former are by common convention taken to be conclusive of the latter. Similarly, The Federalist Papers are by common convention now presumed to constitute authoritative (and convenient) evidence of the intent of the Framers, although any historian could easily demonstrate the empirical inadequacy of the presumption. This tension between the kind of evidence of intent necessary to legitimate political authority and the kind of evidence of intent necessary to persuade professional historical judgment illustrates the truth of 
Nietzsche's remark that "history, so far as it serves life, serves an unhistorical power." ${ }^{3}$ Third, historical interpretation need not focus on the intentions of the Framers or Ratifiers at all, but may attempt instead to ascertain consent through inquiries aimed at altogether different kinds of evidence. ${ }^{54}$

Ultimately, therefore, the infrequency of historical interpretation in contemporary constitutional interpretation may stem less from evidentiary difficulties than from the intrinsic limitations of any theory of interpretation resting on the authority of consent. If that authority is understood to arise at the moment of the Constitution's ratification, then in fact no living person has "consented" to the First Amendment, or indeed to most of the Constitution. Why, it may be asked, should the consent of our predecessors have authority over us? ${ }^{55}$ When faced with this difficulty, consent theorists often resort to notions of "implied" or "tacit" consent, notions that rapidly drain the concept of consent of its ability to legitimate authority. These notions have a stopgap, jerry-built quality that renders them ultimately unsatisfactory. ${ }^{56}$ In fact Hanna Pitkin has demonstrated that principled consent theorists like Locke or Joseph Tussman, when seriously pressed with the absence of actual consent, transform the issue into a question of hypothetical consent. "True authority" thus "emerges as being one to which [persons] ought to consent, quite apart from whether they have done so." 57

A similar transformation is visible in the arena of constitutional interpretation. Thus it is said that even if the "legitimacy" of the Constitution cannot rest upon a prior act of consent, it may nevertheless be founded on the fact that persons now ought to view it as "a good Constitution and therefore one worthy of continuing support." ${ }^{58}$ This is essentially the form of constitutional authority appealed to by Justice Brennan in his dissent in Chambers. Because interpretation founded on this form of authority must ultimately be accountable to contemporary concepts of value, I shall call it "responsive interpretation."

The authority of ethos. The classic statement of responsive interpretation is by Oliver Wendell Holmes:

When we are dealing with words that are also a constitutent act, like the Constitution of the United States, we must realize that they have called into life a being the development of which could not have been foreseen completely by the most gifted of its begetters. It was enough for them to realize or to hope that they had created an organism; it has taken a century and has cost their successors much sweat and blood to prove that they created a nation. The case before us must be considered in the light of our whole experience and not merely of what was said a hundred years ago..$^{59}$

For Holmes the authority of the Constitution is not exhausted in a single creative act of consent, but continues to inhere in the national "being" that the Constitution has "called into life." Hence the nature of that authority can be captured neither by rules laid down in judicial precedents, nor by notions of original inten- 
tion. The authority must rather be conceived as flowing from the "whole experience" of nationhood. That experience legitimately claims our allegiance because we are necessarily included within it, and hence responsible both for what it has been and what it might become. What is authoritative is thus neither more nor less than our common commitment to the flourishing of the mutual enterprise of nationhood.

The radical and paradoxical implication of this perspective is that the Constitution explicitly loses its character as a specific document or a discrete text. It becomes instead, as Karl Llewellyn bluntly put it, a "going Constitution," a "working Constitution" which has a content that "is in good part utterly extraDocumentary," and which represents the "fundamental framework" of "the governmental machine." ${ }^{\circ 0}$ In this way the Constitution is transformed into what Kant might call the "regulative" idea of the enterprise of constitutional adjudication, the "imaginary focus from which the concepts" of that enterprise "seem to proceed, even though there is nothing knowable at that focus." 61

The Constitution as a regulative idea defines the telos and shape of constitutional interpretation: it demands a continual effort to articulate the authority of our "fundamental nature as a people" and hence concomitantly to summon "us to our powers as co-founders and to our responsibilities," in the full knowledge that "how we are able to constitute ourselves is profoundly tied to how we are already constituted by our own distinctive history." 62 In this sense responsive interpretation requires judges to view the Constitution as a form of what Philippe Nonet and Philip Selznick have called "responsive law," law that submits to "the sovereignty of purpose" by functioning "as a facilitator of response to social needs and aspirations." 63

There is a tension, however, between using law to implement a succession of merely present purposes, and using law to sustain the "general ends" 64 constitutive of our "fundamental framework" of governance. The authority of constitutional law inheres only in the latter, for it alone claims fidelity to the "whole experience" that has comprised "our distinctive history." To maintain its legitimacy, therefore, responsive interpretation must be oriented toward the kind of general ends that have been closely linked over the long run to an historical instantiation of national identity. But such ends can provide the basis for adjudication only if they can also "be made objective enough and authoritative enough to control adaptive rule making." ${ }^{5}$ In this regard Justice Brennan's dissent in Chambers is paradigmatic. His effort to inquire into "the underlying function of the Establishment Clause" is specific enough to engender legal consequences, but general enough to express a deep vision of the secular nature of the American state.

Although the theory of responsive interpretation sounds exotic, responsive interpretation is in fact rather common in judicial opinions (certainly much more so than historical interpretation). In the area of the First Amendment's guarantee 
of freedom of speech, for example, the outcome of cases depends upon whether judges perceive the purpose of that freedom to be that of assuring an "unfettered interchange of ideas for the bringing about of political and social changes desired by the people," 66 or instead that of fostering "individual liberty and dignity." ${ }^{67}$ In the area of the constitutional right to privacy, the outcome of cases depends upon whether judges conceive the purpose of the Due Process Clause to be that of safeguarding those "liberties that are 'deeply rooted in this Nation's history and tradition," "68 or instead that of protecting intimate decisions of a kind that "define one's identity." 69

Responsive interpretation is in fact a vast umbrella sheltering a myriad of different approaches to the Constitution. It need not have the specifically liberal cast that is visible in Brennan's dissent in Chambers. It can be used by those who stress the constitutional priority of democratic decision making and hence who emphasize judicial caution and prudence, as well as by those who stress the constitutional primacy of individual rights. It has commonly been used by judges and scholars of both the Right and the Left.

Responsive interpretation does, however, have an important vulnerability. It contains within it no particularly persuasive response to the counter-majoritarian difficulty. If doctrinal interpretation portrays courts as merely the instruments of the law, if historical interpretation portrays courts as merely the instruments of an original democratic will, responsive interpretation portrays courts instead as arbiters of the fundamental character and objectives of the nation. And why, it may be asked, should courts be entrusted to act in that capacity, particularly when in doing so they set aside alternative visions of the national character and objectives propounded by the democratically elected branches of government?

One possible response to this question, which is increasingly visible in the literature, is to stress Hans-Georg Gadamer's theory that all interpretation necessarily involves a conversation between a reader and a text, and so effects a merger between a text and a reader's own purposes and perspectives. Even if this theory is accepted, however, it does not repair the vulnerability of responsive interpretation. This is because the theory's thrust is entirely to describe the conditions that make reading possible, and hence it can offer no guidance to the judge who, having determined the original intent of the Framers to the best of his ability (and therefore in a manner necessarily influenced by his own perspective), must decide whether to be bound by that determination (like Chief Justice Burger in Chambers), or instead to set it aside in favor of a more self-consciously responsive approach (like Justice Brennan in Chambers). The implications of hermeneutic insights for theories of constitutional interpretation are thus quite modest, a fact that is recognized by its more sophisticated proponents.

The acknowledgment of these limitations is, for example, the point of David Hoy's distinction between the "application" of a text, which is "a prior cognitive operation where we first find the text to be saying something to us," and the 
"appropriation" of a text, which is "a willful, self-conscious act": "Application is not an option and is not subjective. But appropriation (e.g., making the text seem more rather than less relevant) is an optional strategy, such that it can be used or avoided." ${ }^{70}$ Responsive interpretation is a matter of appropriation, and as such cannot be defended by the hermeneutic turn.

\section{IV}

We are thus in a position to connect each of the three theories of constitutional interpretation displayed in Chambers to a different conception of constitutional authority. Doctrinal interpretation, which follows the principle of stare decisis, invokes the authority of the Constitution as law. Historical interpretation, which implements an original act of will, is validated by the authority of the Constitution as consent. Responsive interpretation, which engages in an ongoing process of national self-definition, appeals to the authority of the Constitution as, for lack of a better word, ethos.

I will not make the strong claim that these are the only possible conceptions of constitutional authority (and hence the only possible theories of constitutional interpretation), but I will make the more modest descriptive claim that these three conceptions dominate the actual practice of constitutional adjudication. All the many methods of constitutional interpretation that have proliferated in the legal literature of the past decade, ranging from those that stress the values of democratic participation to those that stress the values of autonomous individualism, ${ }^{71}$ ultimately rest upon one or another of these three conceptions of constitutional authority.

Each of these forms of authority is by itself incomplete and incapable of sustaining the enterprise of constitutional adjudication. The authority of the Constitution as law, for example, requires the authority of either consent or ethos in order to initiate a chain of precedents. The authority of consent and that of ethos, on the other hand, each require doctrinal elaboration in order to find embodiment as law. The authority of consent anchors constitutional interpretation in the democratic principles that are necessary and desirable in a country like the United States, while the authority of ethos offers an indispensable flexibility in the interpretation of a document designed to last for the lifetime of the nation.

Yet if these three forms of authority are on one level systematically interdependent, they are at a different level potentially divergent and incompatible. ${ }^{72} \mathrm{As}$ the Chambers decision illustrates, a court in a constitutional case may be called upon to decide which form of authority should govern its efforts, and its decision may determine the outcome of the case. Because this decision is most often understood to depend upon an antecedent characterization of the Constitution 
(as, e.g., "law," "compact," or "ethos"), arguments about theories of interpretation commonly modulate into arguments about the inherent "nature" of the Constitution. To the extent that the three theories of constitutional interpretation are perceived as incompatible, it is due to the fact that they are seen as flowing from incompatible notions of the Constitution itself.

But this vision of constitutional authority is fundamentally flawed, for it postulates a form of constitutional authority that is external to the processes of its own interpretation. It imagines that the nature of the Constitution can somehow be determined in a manner which is independent of the practice of constitutional interpretation, and that the practice is therefore logically controlled by this antecedent determination of constitutional authority. ${ }^{73}$ But a better account of the practice of constitutional interpretation would situate constitutional authority instead in the relationship obtaining between participants in that practice and the Constitution. Paradoxically, then, constitutional interpretation is not merely about the Constitution but about the more radical and profound question of how we stand in connection to the Constitution.

The nature of the authority of law. If we ask, for example, what it means to defer to the authority of the Constitution as law, the answer is that this authority embodies the values of stability, predictability, and reliance which are necessary to the legitimacy of any modern legal system. Not only are these values themselves important, but they are also the means by which the law orders behavior so as to achieve justice and other desired objectives. The authority of the Constitution as law flows precisely from the acknowledgment of these values.

Once this point is made clear, however, it is also evident that these values, no matter how important, may or may not be compelling in particular circumstances. The values of the rule of law are most pressing when there is agreement that the law is generally just and otherwise fulfilling its proper purposes. In such circumstances doctrinal interpretation and the principle of stare decisis hold the law steady on its course. But if there is disagreement about the justice of the law, or about its purposes, or about its effectiveness in achieving those purposes, then the balance can begin to tip away from the values of stability and predictability. ${ }^{74}$ At a certain point, when dissatisfaction with the status quo reaches a sufficient magnitude, we can expect to see the doctrinal chain snapped. ${ }^{75}$

This means, however, that the authority of the Constitution as law does not stand outside the processes of constitutional interpretation, like an axiom in a geometrical proof, but is rather implicated within that very process. In any specific case we may question whether that authority is compelling enough to mandate a particular result. Thus it is not the antecedent "nature" of the Constitution that requires doctrinal interpretation, but rather the decision to recognize and be 
bound by the values embodied in the authority of the Constitution as law. By acknowledging these values we create a certain relationship to the Constitution, one in which the authority of the rule of law becomes visible and pressing.

In the American legal system this authority appears both flexible and inevitable. It is not disabled even if in particular cases we deny its mandate and break with the principle of stare decisis. That is because when the chain of doctrine is broken and precedent is either explicitly or effectively overruled, a new decision must be announced, and for that decision itself to have any effect, it must be crafted in the form of a rule of law that will be respected according to the principle of stare decisis. This means that doctrinal interpretation is presupposed even in the moments of its repudiation. Thus although the practice of constitutional adjudication at times may and sometimes must depart from doctrinal interpretation, it is a form of interpretation to which the practice will also inevitably return.

The symmetrical nature of the authority of consent and the authority of ethos. If doctrinal interpretation views the Constitution only dimly at one end of a long corridor of precedents, historical and responsive interpretation each confront the Constitution, so to speak, face to face. The directness of this inquiry liberates courts from the chains of doctrine, and empowers them to alter and amend precedents. It also empowers them to uncover and articulate substantive constitutional values. For historical interpretation, this power rests on a court's claim to speak with the authority of an original act of consent. For responsive interpretation, this power rests on a court's claim to speak with the authority of our deepest national identity and commitments. Although these claims appear on their surface to be very different, as different as Burger's majority opinion in Chambers from Brennan's dissent, in fact they each share an underlying structural similarity.

The authority of consent rests on the capacity of the individual voluntarily to assume obligations. Absent special circumstances to the contrary, a person's contracts are viewed as binding and authoritative. This fact has important consequences for constitutional interpretation. Imagine the dismay you would feel, for example, if you were to have worked for and achieved the ratification of a constitutional amendment, say the Equal Rights Amendment, only to have it interpreted by a court in a manner flatly contrary to your intent and to the intent of the amendment's supporters and ratifiers. In such circumstances you would want a judge to subordinate her personal perspectives and faithfully to implement the act of consent by virtue of which the amendment had become authoritative. You would no doubt experience a judge's departure from this duty as a betrayal.

The appeal of historical interpretation trades on this experience of betrayal. It is important to understand, however, that this experience does not depend 
upon anything so simple as the physical casting of a vote. Constitutional amendments are ratified, not by general elections, but by state legislatures or special state conventions. Your experience of betrayal would depend, not upon whether you personally were a member of one of these special ratifying bodies, but rather upon your identification with those who had physically signified their consent. What would count is your sense that the members of the state legislatures or conventions who had actually assented to the Equal Rights Amendment spoke "for" you.

This same identification can extend in time as well as in space. Thus when confronted with constitutional provisions that are a century or more old, historical interpretation can be understood implicitly to assert an identification, a community of interest, with the framers or ratifiers of those provisions. "Their" consent, so the implicit assertion would go, is "our" consent; they spoke "for" us. It follows that the authority of historical interpretation will in significant measure depend upon the persuasiveness of that assertion. That is why in Chambers Chief Justice Burger offers an extended discussion of "the unambiguous and unbroken history of more than two hundred years," which he claims establishes "that the practice of opening legislative sessions with prayer has become part of the fabric of our society." 76 The power of Burger's opinion rests in the end upon a claimed continuity of identification with those who had proposed and ratified the First Amendment.

This claim, however, is neither more nor less than a characterization of the national ethos. It is a claim about our national identity and history. Thus while the debate between majority and dissent in Chambers can at one level be seen as struggle between historical and responsive interpretation, it can at a deeper level be understood as a disagreement about whether we can now identify with our ancestors, or whether we have over the centuries become so different from them, so much more secular or diverse, that we have lost any persuasive identification with the consent of those who ratified the First Amendment. ${ }^{77}$

This deep symmetry between historical and responsive interpretation stems from the fact that both ultimately flow from the authority of a will that affirms its own identity. ${ }^{78}$ Responsive interpretation makes this authority explicit, because it openly affirms responsibility for the nature of our national ethos. While historical interpretation seemingly presents itself as a self-denying submission to the identity of past ratifiers, closer analysis reveals that that identity is authoritative only insofar as we can be persuaded to adopt it as our own. ${ }^{79}$ In either case, the authority of the Constitution ceases to stand apart from the processes of its interpretation. That authority does not flow from the antecedent nature of the Constitution, but rather from the particular relationship we have forged with the Constitution.

In this regard, however, responsive interpretation is unique, for it alone explicitly thematizes this relational nature of constitutional authority. Both his- 
torical and doctrinal interpretation purport to submit to a Constitution whose authority is independent and fixed, either in the preexisting consent of the ratifiers or in the preexisting rules of controlling precedents. Although this submission is illusory, it is an illusion capable of disarming dissent. Responsive interpretation, however, disavows this illusion, and frankly locates constitutional authority in the relationship between the Constitution and its interpreters. As a consequence responsive interpretation generates an intense and singular kind of political dynamics.

A good example is Brown v. Board of Education..$^{80}$ The decision did not turn on what the ratifiers of the Fourteenth Amendment thought, ${ }^{81}$ nor on what the Court had previously held in Plessy v. Ferguson. ${ }^{82}$ Instead the ideal of racial equality had become so pressing to the Court that there was no alternative but to interpret the Equal Protection Clause in light of its imperatives. But precisely because this interpretation rested upon an open avowal of a national ideal, Brown represented a courageous gamble. The Court's embrace of the value of racial equality could have been a misreading of the national ethos; indeed the Court's gamble was intensely controversial and came close to failing precisely because that ethos was in fact so divided. ${ }^{83}$

By refusing to interpret the Constitution as if it were a source of external compulsion, either of past precedent or of past consent, responsive interpretation always places a court in such an exposed position, purporting to speak for the fundamental ethos of the contemporary community, but justified in the end only by the wisdom of its own insight. Under conditions of cultural division, that position can be the platform for a special form of leadership (as in Brown), or it can be the cause of the most unhappy form of vulnerability (as in Roe v. Wade).

$R o e$, which at the time of its decision stood without significant historical or precedential support, ${ }^{84}$ illustrates the structural vulnerability of responsive interpretation to the charge that it articulates values that are merely local and partisan, rather than general and truly constitutive of the nation. The charge is unlikely to surface when there is cultural consensus, because the invocation of contemporary values will under such circumstances be unobtrusive and perhaps even unnoticed. But in the absence of consensus the frank ambition of responsive interpretation to "speak for" the character of the nation, while expressive of the outlook of some, will necessarily constitute a hegemonic imposition upon others. ${ }^{85}$ Thus the enterprise of responsive interpretation can become the locus of an overt struggle for the definition of national identity. In the legal academy responsive interpretation has been profoundly controversial because of the unease generated by perceived judicial participation in such a struggle.

Paradoxically, however, the root cause of this unease is precisely responsive interpretation's explicit thematization of the relational nature of constitutional authority, a form of authority that it in fact shares with both historical and doctrinal interpretation. 
The inevitability of responsive interpretation. Responsive interpretation is in some respects similar to what in the contemporary legal literature is called "noninterpretivism," 86 which can roughly be defined as that form of constitutional interpretation which seeks "the principal stuff of constitutional judgment in one's rendition of society's fundamental values rather than in the document's broader themes." 87 Noninterpretivism, and by extension responsive interpretation, is frequently attacked as breaking faith with a judge's obligation to interpret the Constitution rather than to enact her own desires.

Understood in a psychological sense, the attack is clearly justified. If a judge believes that the Constitution means $\mathrm{X}$, but the judge decides $\mathrm{Y}$ because she prefers $\mathrm{Y}$, the judge's decision is presumptively illegitimate. But this framing of the issue is ultimately trivial, for it proceeds on an assumption of bad faith, and it prejudges the critical question, which is the nature of that Constitution to which the judge should maintain fidelity. If noninterpretivism is defined as rendering judgment upon the basis of extraconstitutional factors, then it will of course be vulnerable, but only in an uninteresting and merely stipulative sense. Properly understood, however, responsive interpretation avoids this vulnerability by including the additional claim that our "fundamental nature as a people" is part of the legitimate authority of the Constitution.

One objection to responsive interpretation, therefore, is that it mistakes the "root premise" of American constitutionalism, which is "that the Supreme Court, like the other branches of government, is constrained by the written constitution." ${ }^{8}$ The point is that responsive interpretation, which explicitly dissolves the Constitution as a specific written text, rests on an unacceptable notion of the Constitution. The force of this objection, which is considerable, derives from the circumstance in which the words of the Constitution appear to speak plainly to us. Recall the case of the third California senator, which a court could settle merely by reading the text of the document. In such a case it seems as if the document itself were authoritative, as if meaning flowed naturally from that handwritten, hand-signed parchment kept under glass in the National Archives. ${ }^{89}$ It would appear to follow that any theory of interpretation which abandons that document is illegitimate.

This reasoning, however, proves far too much. It is true that when the document's meaning is unproblematic we feel constrained to regard its language as authoritative without further inquiry. But when for whatever reason the document's meaning does seem problematic, we are necessarily forced outside the text in search of some authority to guide our interpretation of the text. Thus every theory of constitutional interpretation is at some level inconsistent with the notion of a narrow fidelity to a written document. Doctrinal interpretation, for example, which is the sine qua non of constitutional adjudication, applies not the words of the document, but legal rules that judges have subsequently created. Most constitutional cases are decided on the basis of doctrinal "tests" that have very little 
to do with the text of the parchment which resides in the National Archives. Even historical interpretation looks for authority not to the text of the written document, but rather to the consent of those who agreed to it. The charge that responsive interpretation abandons the written document, therefore, is an accusation that would disqualify virtually all forms of constitutional interpretation.

A second objection to responsive interpretation, however, is that it abandons the document in a particularly unacceptable way. Historical interpretation focuses on an original act of consent because that consent "points toward" the document and illuminates its specific meaning. Doctrinal interpretation, it might be said, focuses on rules of precedent because such rules also "point toward" the document and are attempts to elucidate its meaning. Responsive interpretation, on the other hand, turns away from the document altogether in an effort to uncover present values.

This objection captures what I take to be a major animus of the contemporary debate, and for that reason it needs to be carefully parsed. It is true that because historical interpretation looks to the consent of the ratifiers, the historical document actually ratified is central to the interpretative enterprise. But doctrinal interpretation can be said to "point toward" that document only in the most attenuated metaphorical sense, a sense in which it is equally true to say that responsive interpretation "points toward" the document.

Responsive interpretation rests on the claim that the Constitution is not "static and lifeless," to use Brennan's words in Chambers. Instead, as Holmes put it, the Constitution is understood as having "called into life a being" that, like any "organism," must grow and develop on the basis of its "experience." ambition and challenge of responsive interpretation is to determine which aspects of our contemporary ethos may be regarded as legitimate "growth from the seeds which the fathers planted," and hence as bearing "the essential content and the spirit of the Constitution." ${ }^{11}$ Only these aspects of the national ethos are genetically related to the document and thus may properly form the basis for responsive interpretation. In this sense responsive interpretation does indeed "point (backward) toward" the document, in at least as strong a metaphoric sense as does doctrinal interpretation.

Admittedly the organic metaphor that underlies this account of responsive interpretation is highly problematic. It is important to understand, however, that responsive interpretation could equally well rest upon other and perhaps more convincing metaphors. It could invoke, for example, the image of an evolving "tradition" that is constitutive of cultural meaning ${ }^{92}$ Or it could adopt the sociological language of communitarianism, as in this passage from Philip Selznick:

A social contract is a constitutive contract. Its function is to create a political community by founding the legitimacy of government on the consent of the governed. Once the community is formed it has a logic and a dynamic of its own. Even the fundamental obligations of government and citizenry-obligations of loyalty, self-restraint, and care-flow from 
the nature of the community and of its historical premises, not from the terms of an agreement. ${ }^{93}$

Each of these metaphors can be used to describe a national ethos that both changes over time and yet also manages to retain a distinctive identity. Each portrays a national ethos in which we are implicated, and to which we are therefore responsible. Each is therefore capable of sustaining the enterprise of responsive interpretation.

In these heady days of postmodernism, of course, it is easy enough to deny the truth of all these metaphors, and to repudiate the very existence of any overarching national ethos. The political consequences of such a denial, however, are grim. They were in fact first systematically articulated by Thomas Hobbes, and today the premises of his work remain visible in the writings of those influenced by economics and public choice theory. A clear example can be found in the views of a constitutional scholar like Robert Bork, who argues that there is no such thing as a distinctive national ethos, but only a vast collection of individual preferences. ${ }^{94}$ It follows from this perspective that any attempt to interpret the Constitution on the basis of the authority of a national ethos will necessarily degenerate into an unwarranted imposition of private judicial preferences. ${ }^{95}$

Two preliminary points should be made about this perspective. First, it is inconsistent with historical interpretation, with which it is sometimes associated. Historical interpretation rests on the implicit assertion that the national ethos supports an identification with the ratifiers of the Constitution. But if there are only discrete individual preferences, and if the nation does not have any national ethos, there is no reason whatever why the consent of those long dead should hold any particular authority for the present generation. Second, as the example of Hobbes illustrates, this perspective has difficulty offering a plausible account of political authority as anything other than a collective need for forceful and clear rules of conduct to save individuals from the destructive consequences of their own egoism. But this form of authority, stressing as it does the values of continuity and predictability, is compatible only with the authority of the Constitution as law, which is to say with doctrinal interpretation. The actual implication of this perspective, therefore, is that the principle of stare decisis should hold until interrupted by contemporaneous processes of constitutional amendment.

The consequences of denying the existence of a national ethos are thus dramatic, far-reaching, and singularly unattractive. It transforms the overriding concern of constitutional adjudication into the maintenance of rules (any rules), for only such rules stand between us and a chaos of individual desires. Because the primary objective of these rules will be the preservation of order, those subject to constitutional rules will necessarily be reduced "to mere objects of the administered life." 96 The Constitution is thus ultimately converted into a form of "repressive law" that "gives short shrift to the interests of the governed."97 
This transformation is relevant to an assessment of the position of scholars like Bork. Although the existence or absence of a national ethos appears at first blush to be an empirical question that is independent of the perspective of a court, in fact matters are not so simple. As the example of Brown v. Board of Education illustrates, a court can, through the eloquent articulation of public ideals, actually help to solidify a national ethos. The national ethos to which responsive interpretation appeals, in other words, may in significant ways be affected by the very practice of responsive interpretation. The question facing a court, therefore, is whether it should interpret the Constitution in ways that may express or establish a national ethos, or whether it should do so in ways that may confirm its absence. I think this question answers itself, which is why constitutional interpretation has never at any time proceeded on Hobbesian premises.

There is, however, yet a fourth objection to responsive interpretation, one which exerts considerably more influence than the Hobbesian perspective. It does not deny that the nation has an ethos which forms an important component of its public life, but it contends that it is inappropriate for judges to appeal to that ethos as a form of constitutional authority, because the conservation and articulation of that ethos should be placed in the hands of democratically elected officials rather than judges. The objection, in other words, rests on an institutional analysis of how courts ought to function in a democracy. It is of course on precisely such institutional considerations that the counter-majoritarian difficulty is ultimately founded. The stubborn persistence of the difficulty suggests the presence of powerful truths that cannot be brushed aside.

They are, however, only partial truths. If the Constitution is not to degenerate into merely repressive law, authoritative only because of the need for clear and predictable rules, courts interpreting the Constitution must be allowed to speak from the authority of a national ethos, in the form of either historical or responsive interpretation. Taken to its logical conclusion, therefore, the countermajoritarian difficulty leads to exactly the same unacceptable vision of constitutional law as that which flows from overtly Hobbesian premises. ${ }^{98}$ But this consequence is unacceptable to proponents of the counter-majoritarian difficulty, for the institutional considerations by which they seek to circumscribe judicial power are themselves based on a particular account of the national ethos, one that characteristically stresses the importance of majority will in the form of government created by the Constitution. ${ }^{99}$ Proponents of the counter-majoritarian difficulty are thus torn between their account of appropriate institutional principles and the fact that these principles, if fully implemented, would preclude judges from appealing to the very national ethos from which the principles flow.

Institutional objections to responsive interpretation are consequently riven by internal tensions. For this very reason, however, institutional objections have rarely if ever implied a simple repudiation of responsive interpretation. Instead they have characteristically generated counsels of caution, urgent recommenda- 
tions that responsive interpretation be used only sparingly and in ways consonant with the underlying conception of the national ethos upon which the institutional objections are themselves based. They have led, in other words, to forms of responsive interpretation based upon a particular understanding of the national ethos as founded upon majoritarian principles. ${ }^{100}$

\section{$\mathbf{V}$}

The fact that identical judges use different theories of constitutional interpretation in different cases is often used as evidence of the unprincipled nature of constitutional law. And, indeed, if the choice of an interpretative theory depended on the nature of the Constitution, and if that nature were antecedently and externally given, it would be difficult to condone the ways in which judges actually use interpretative theories. But if, as I have argued, constitutional interpretation depends instead upon a relational concept of constitutional authority, judges can legitimately select a specific interpretative theory in light of the circumstances of a particular case.

Thus a court can justifiably use historical interpretation with respect to an issue in a case if it believes that the national ethos supports an identification with a past act of consent relevant to that issue. But it can justifiably use responsive interpretation if it can discern with respect to that issue the presence of a national ethos that in a pertinent way historically embodies the essential content and spirit of the Constitution, and that precludes identification with any past act of consent. Hence the choice between historical and responsive interpretation can turn on an appraisal of the national ethos.

The selection of doctrinal interpretation entails a different kind of appraisal, one that requires a court to determine whether the values of the rule of law outweigh the inadequacy of controlling precedents. An important reason why precedents may be inadequate is that they are inconsistent with the interpretation of the Constitution required by the national ethos, either in the form of historical or responsive interpretation. The striking of this balance between the rule of law and the national ethos is both necessary and legitimate.

Thus the selection of a specific theory of constitutional interpretation for a particular case can be justified in the same way that any legal decision can be justified. Justification flows not from logical compulsion but rather from the principled application of pertinent considerations. Constitutional adjudication, like all law, is in this way revealed as balanced on the human faculty of judgment. As in all human endeavor, pertinent considerations may be more or less compelling, and consequently the ability to exercise judgment more or less sustained.

Nevertheless, the pattern of judgment in constitutional law can reveal a good deal about the nature of fundamental authority in our democratic state. It sug- 
gests, for example, that visions of the national ethos, and hence of a "humanly meaningful authority," ${ }^{101}$ are at the core of our practice of constitutional adjudication. This is encouraging news to set against the view of those who, like Jürgen Habermas and others, perceive the tidal current of this century as flowing toward "undeviating organization," 102 with its concomitant conditions of bureaucracy, alienation, deracination, and instrumental rationality. But it is also cause for concern if, as appears increasingly likely to be the case for many of us, the vision of national ethos authoritatively enacted by the Supreme Court is contrary to our own. Our consolation in such circumstances is the strength that Claude Lefort identifies with modern democracy: the ever-present possibility that our protests will create a reconstituted political perspective that will in turn alter the character of future judicial appointments.

But that possibility, of course, simply pulls Ernest Chambers round full circle, back to his original efforts to convince his fellow legislators of the deep impertinence of legislative prayer.

\section{Notes}

1. Claude Lefort, Democracy and Political Theory, trans. David Macey (Minneapolis, 1988), 39.

2. Testimony of Ernest Chambers, Marsh v. Chambers, 463 U.S. 783 (1983), joint appendix at 20, 23-24, 27.

3. Testimony of Robert E. Palmer, ibid. at 40-41, 45, 51, 83, 89; exhibit 1, 1975 Prayer Book, 4 April 1975, ibid. at 96; exhibit 2, 1977-78 Prayer Book, 7 February 1977, ibid. at 98 .

4. Although the clause speaks only of Congress, it has been held to be binding on the states by virtue of the Fourteenth Amendment.

5. 504 F. Supp. 585 (D. Neb. 1980).

6. 675 F. 2nd 228 (8th Cir. 1982).

7. I stress the phenomenological character of this point. It is of course quite plausible to contend that all reading is necessarily active, and hence "interpretative." But not all reading requires a reader self-consciously to inquire into the meaning of a text. From a phenomenological point of view, therefore, some reading does not require that the process of interpreting a text be thematized.

8. United States v. Butler, 297 U.S. 1, 62 (1936).

9. It is necessary at this point to distinguish between textualism as a putative "theory" of interpretation, designed to reveal the meaning of an uncertain text, and textualism as a rule of evidence or priority, which is designed either to exclude from consideration data from beyond the four corners of the document or else to assign to the language of the text priority over such data. Textualism as a rule of evidence or priority would follow from, and presumably be justified by, an anterior theory of interpretation.

10. On the relationship between interpretation and situations where "meaning is 
doubtful," see Marcelo Dascal and Jerzy Wroblewski, "Transparency and Doubt: Understanding and Interpretation in Pragmatics and in Law," Law and Philosophy 7 (1988): 203-24. It is clear, as Dascal and Wroblewski point out, that the distinction between meaning that is plain, that "fits the case under consideration directly and unproblematically, as a glove to a hand," and meaning that is questionable is not one that turns on the "inherent quality of a legal text" but is rather "pragmatic" in nature, turning on all the factors involved "in a given communicative situation" $(215,221)$.

11. Marbury v. Madison, 5 U.S. (1 Cranch) 137, 176 (1803).

12. Ibid. at 163. The phrase was made famous in America by John Adams, who had appointed Marshall to the bench; in Marbury Marshall wickedly used it to pinion John Adams's archenemy, Thomas Jefferson. For the derivation of the phrase, see Frank Michelman, "Foreword: Traces of Self-Government," Harvard Law Review 100 (1986): 4, n. 2; 40-41. For a discussion of other strange circumstances surrounding Marbury, see John A. Garraty, "The Case of the Missing Commissions," in Garraty, ed., Quarrels That Have Shaped the Constitution (New York, 1964).

13. Marbury v. Madison, 5 U.S. at 163, 175.

14. Alexander Bickel, The Least Dangerous Branch (Indianapolis, 1962), 16-17.

15. Dred Scott v. Sandford, 60 U.S. (19 How.) 393 (1857).

16. Marsh v. Chambers, 463 U.S. at 796 (Brennan, J., dissenting).

17. See Richard A. Wasserstrom, The Judicial Decision: Toward a Theory of Legal Justification (Stanford, Calif., 1961), 39-83.

18. For a discussion of the nature of the rule of law, see Joseph Raz, "The Rule of Law and Its Virtue," in The Authority of Law (Oxford, 1979), 210-19.

19. For further discussion, see Melvin Aron Eisenberg, The Nature of the Common Law (Cambridge, Mass., 1988), 47-49.

20. Henry Paul Monaghan, "Stare Decisis and Constitutional Adjudication," Columbia Law Review 88 (1988): 752 (quoting Archibald Cox, The Role of the Supreme Court in American Government [New York, 1976], 50). See Vasquez v. Hillery, 474 U.S. 254, 26566 (1986); Roscoe Pound, "What of Stare Decisis?” Fordham Law Review 10 (1941): 2.

21. 675 F. 2nd at 233.

22. Lemon v. Kurtzman, 403 U.S. 602, 612-13 (1971). See Comm. for Public Education and Religious Liberty v. Nyquist, 413 U.S. 756, 773 (1973).

23. Marsh v. Chambers, joint appendix at 49.

24. California Senate Journal, 37th sess. (1907), 171-73, 307-8, 805-6, 808, 818-21.

25. Marsh v. Chambers, 63 U.S. at 801.

26. Ibid. at 786-88. 27. Ibid. at 788,790 .

28. This was essentially the position advocated by the solicitor general in his brief for the United States as amicus curiae. The solicitor general argued that in Chambers "analysis of the legislative chaplaincy practice under the Lemon test seems pointless" because "historical analysis ... should alone suffice to demonstrate that the Nebraska chaplaincy" was consistent with "the intended meaning and scope of the Establishment Clause"; ibid., Brief for the United States, at 21-22.

29. Ibid. at 801 . 30. Ibid. at 802-5.

31. Ibid at 816-17. As Brennan has subsequently explained: "I frankly concede that I approach my responsibility as a justice, as a 20th century American not confined to [the] framers' vision in 1787. The ultimate question must be, I think, what do the words of the Constitution and Bill of Rights mean to us in our time"; address by William Brennan at Hyde Park, New York, The Recorder, 8 November 1989, 8. 
32. Paul W. Kahn, "Reason and Will in the Origins of American Constitutionalism," Yale Law Journal 98 (1989): 504.

33. William W. Van Alstyne, "The Idea of the Constitution as Hard Law," Journal of Legal Education 37 (1987): 179. For a useful symposium on the subject, see Constitutional Commentary 6 (1989): 19-1 13.

34. Osborne v. Bank of the United States, 22 U.S. (9 Wheat.) 326, 381 (1824).

35. Eisenberg, Nature of Common Law, 158-59.

36. See J.M. Balkin, "Constitutional Interpretation and the Problem of History," New York University Law Review 63 (1988): 928.

37. Minneapolis Star and Tribune Co. v. Minnesota Commissioner of Revenue, 460 U.S. 575, 583, n. 6 (1983).

38. Lest this analysis seem too hypothetical, it should be noted that from 1967 until 1973 the Supreme Court decided thirty-one obscenity cases without opinion because it was unable to agree on a rule of law to distinguish obscene from nonobscene speech. See Frederick F. Schauer, The Law of Obscenity (Washington, D.C., 1976), 44

39. For a similar argument in the context of statutory interpretation, see Edward H. Levi, An Introduction to Legal Reasoning (Chicago, 1949), 30-33.

40. In speaking of "legal implications," of course, I am excluding the immediate impact of the decision on the parties to the case. The effect of the Chambers decision on the Nebraska state legislature is, at least for purposes of Chambers's specific lawsuit, independent of the principle of stare decisis. That principle only determines the effect of the decision on other, similarly situated legislatures.

41. Frederick F. Schauer, "Formalism," Yale Law Journal 97 (1988): 509-48.

42. See Ronald Dworkin, Law's Empire (Cambridge, Mass., 1986).

43. Paul Brest, "The Misconceived Quest for the Original Understanding," Boston University Law Review 60 (1980): 234.

44. Speech of Attorney General Edwin Meese III before the American Bar Association, 9 July 1985, Washington, D.C., in The Great Debate: Interpreting Our Written Constitution (Washington, D.C., 1986), 9.

45. Charles Fried, "Sonnett LXV and the 'Black Ink' of the Framers' Intention," Harvard Law Review 100 (1987): 759. See H. Jefferson Powell, "The Original Understanding of Original Intent," Harvard Law Review 98 (1985): 895-98. This version of historical interpretation might, for example, justify textualism as a rule of evidentiary exclusion. See note 9 above.

46. Monaghan, "Stare Decisis," 725.

47. See Raoul Berger, Federalism: The Founders' Design (Norman, Okla., 1987), 13-20.

48. The undeniable force of this conclusion also illustrates the ease with which constitutional interpretation escapes from the specific and plain words of the constitutional text.

49. For an elaboration of this argument, see Ronald Dworkin, A Matter of Principle (Cambridge, Mass., 1985), 33-57.

50. This was also James Madison's position; see The Writings of James Madison, ed. Gaillard Hunt, vol. 6 (New York, 1900), 272; Powell, “Original Understanding," 937-38.

51. Marsh v. Chambers, 463 U.S. at 815, n. 32; quoting Bernard Schwartz, The Bill of Rights: A Documentary History, vol. 2 (New York, 1971), 1171.

52. Gerald C. MacCallum, Jr., "Legislative Intent," Yale Law Journal 75 (1966): 766-69.

53. Friedrich Nietzsche, The Use and Abuse of History, trans. Adrian Collins (Indianapolis, 1957), 11. Hence the notorious "illicit love affair" between "Clio and the Court"; 
Alfred H. Kelly, "Clio and the Court: An Illicit Love Affair," Supreme Court Review (1965): 119-58.

54. See p. 21 above.

55. For a discussion, see Brest, "Misconceived Quest," 225-26.

56. For the definitive analysis of this point, see David Hume, A Treatise of Human Nature, 2nd ed., ed. L. A. Selby-Bigge (Oxford, 1978), 534-53.

57. Hanna Pitkin, "Obligation and Consent," in Peter Laslett, W. G. Runciman, and Quentin Skinner, eds., Philosophy, Politics, and Society, 4th ser. (Oxford, 1972), 62.

58. Daniel A. Farber, "The Originalism Debate: A Guide for the Perplexed," Ohio State Law Journal 49 (1989): 1099-1 100.

59. Missouri v. Holland, 252 U.S. 416, 433 (1920).

60. Karl Llewellyn, "The Constitution as an Institution," Columbia Law Review 34 (1934): $14-15,26$.

61. J. N. Findlay, Kant and the Transcendental Object: A Hermeneutic Study (Oxford, 1981), 241.

62. Hanna Pitkin, “The Idea of a Constitution,” Journal of Legal Education 37 (1987): 167, 169.

63. Philippe Nonet and Philip Selznick, Law and Society in Transition: Toward Responsive Law (New York, 1978), 14-15, 78.

64. Ibid., 79.65 . Ibid., 77.

66. Dun and Bradstreet, Inc. v. Greenmoss Builders, Inc., 472 U.S. 749, 759 (1985) (opinion of Powell, J.).

67. Ibid. at 787 (Brennan, J., dissenting).

68. Bowers v. Hardwick, 106 S. Ct. 2841, 2844 (1986).

69. Ibid. at 2851 (Blackmun, J., dissenting).

70. David Couzens Hoy, "A Hermeneutical Critique of the Originalism/Nonoriginalism Distinction," Northern Kentucky Law Review 15 (1988): 493, 495.

71. For a good survey, see Walter F. Murphy, James E. Fleming, and William F. Harris, Jr., American Constitutional Interpretation (New York, 1986).

72. Of course they need not be incompatible. Each of the three conceptions of authority can be understood in ways that render it functionally indistinguishable from the others. Thus an original act of consent can be construed as mandating on the one hand the rule of law, or on the other a continual, open sensitivity to the national ethos. The national ethos can be interpreted to require fidelity to precedent or submission to the founders' consent; the principle of stare decisis can be implemented in such a way as to express either the national ethos or the imperatives of an original act of consent.

The point, however, is that these potential convergences are merely contingent, and hence not truly dispositive of the distinctions that divide the three conceptions of constitutional authority. For example, a judge who argues that constitutional authority resides in an original act of consent that also happens to mandate sensitivity to an evolving national ethos is committed to the position that such sensitivity would be improper if the content of that consent were different. Thus for such a judge the discernment of consent would retain a privileged position.

73. For a path-breaking critique of this approach, see Philip Bobbitt, Constitutional Fate: Theory of the Constitution (New York, 1982).

74. As I write this, for example, the survival of a woman's constitutional right to terminate a pregnancy within the first two trimesters depends to no small extent upon the 
value assigned by the Supreme Court to the principle of stare decisis; see Webster $v$. Reproductive Health Services, 109 S. Ct. 3040, 3056-57 (1989) (opinion of Rehnquist, C. J.); ibid. at 3078 (Blackmun, J., dissenting); Akron v. Akron Center for Reproductive Health, 462 U.S. 416, 419 (1983).

75. For examples, see United States v. Scott, 437 U.S. 83, 86-87 (1978); Garcia v. San Antonio Metropolitan Transit Authority, 469 U.S. 528 (1985). It is particularly important that past precedent not be entirely decisive "in cases involving the Federal Constitution, where correction through legislative action is practically impossible," Burnet $v$. Coronado Oil and Gas Co., 285 U.S. 393, 405-8 (1932) (Brandeis, J., dissenting), and hence where, since the practice of constitutional amendment is so cumbersome and impractical, correction can in many circumstances only come as a practical matter when the Court itself turns away from stare decisis. For this reason the Supreme Court has a "considered practice not to apply stare decisis as rigidly in constitutional as in nonconstitutional cases"; Glidden Co. v. Zdanok, 370 U.S. 530, 543 (1962) (opinion of Harlan, J.). See Patterson v. McLean Credit Union, 109 S. Ct. 2363, 2370-71 (1989).

76. Marsh v. Chambers, 463 U.S. at 792.

77. This suggests that we should expect to see historical interpretation predominate (at least in cases of first impression) in the years immediately following the ratification of a constitutional provision. During that time there will be an obvious and perceptible identification with the process of consent. But as the years pass, and as the connections to that process fade, the assumption of identification may become increasingly less plausible or persuasive. Changed circumstances or altered cultural conditions may make the consent of the ratifiers seem foreign or alien, quite unlike our own consent. It is at such moments that one would anticipate a transition from historical to responsive interpretation. Llewellyn offers a marvelous description of this process in "Constitution as Institution," 12-15.

78. In the words of Don Herzog, "The consent of the governed is a special case. It hangs not on the choices made by individuals but on the responsiveness of the state to the people, taken as a collective body"; Happy Slaves: A Critique of Consent Theory (Chicago, 1989), 215.

79. It is of course possible to argue that we should be bound by the ratifiers' will even if it does not reflect our own. But then it must be explained why this is the case, and that explanation cannot invoke the authority of consent. One possible explanation is that the government couldn't function if decisions made according to appropriate democratic procedures were to lose their authority simply because the passage of time had altered the relevant democratic constituency. But this explanation, stressing as it does the necessity for the Constitution to remain in effect as law in order to sustain the values of continuity, reliance, and predictability, would logically lead to a form of doctrinal, rather than historical, interpretation.

80. Brown v. Board of Education, 346 U.S. 483, 489-95 (1954).

81. For a discussion of the incompatibility of Brown with any form of historical interpretation, see Monaghan, "Stare Decisis," 728.

82. Plessy v. Ferguson, 163 U.S. 537 (1896).

83. See, e.g., Cooper v. Aaron, 358 U.S. 1 (1958).

84. John Hart Ely, Democracy and Distrust (Cambridge, Mass., 1980), 2-3. In recent years, with the advantage of hindsight, more convincing arguments have been made that Roe could seriously be justified as a form of doctrinal interpretation.

85. For a discussion of the distinction between expressive and hegemonic functions of law, see Robert C. Post, "Cultural Heterogeneity and Law: Pornography, Blasphemy, and the First Amendment," California Law Review 76 (1988): 299-300. 
86. See Thomas C. Grey, "Do We Have an Unwritten Constitution?" Stanford Law Review 27 (1975): 703-18; David Lyons, "A Preface to Constitutional Theory," Northern Kentucky Law Review 15 (1988): 459-98.

87. Ely, Democracy and Distrust, 88 , note.

88. Henry Paul Monaghan, "Our Perfect Constitution," New York University Law Review 56 (1981): 375-76 (emphasis added).

89. For the fascinating suggestion that we may have actually enshrined the wrong document, see Akhil Reed Amar, "Our Forgotten Constitution: A Bicentennial Comment," Yale Law Journal 97 (1987): 281-98.

90. For a brief discussion of the history of "organic" metaphors of the Constitution, see Michael Kammen, A Machine That Would Go of Itself: The Constitution in American Culture (New York, 1986), 19-20.

91. The words are those of Chief Justice Charles Evans Hughes, in Home Building and Loan Assoc. v. Blaisdell, 290 U.S. 398, 443-44 (1934).

92. See, e.g., Hans-Georg Gadamer, Truth and Method (London, 1975); Alasdair MacIntyre, After Virtue (Notre Dame, Ind., 1981).

93. Philip Selznick, "The Idea of a Communitarian Morality," California Law Review 75 (1987): 451

94. On the distinction between preferences and values, see Mark Sagoff, "Values and Preferences," Ethics 96 (1986): 301-14.

95. "Every clash between a minority claiming freedom and a majority claiming power to regulate involves a choice between the gratifications of the two groups. When the Constitution has not spoken, the Court will be able to find no scale, other than its own value preferences, upon which to weigh the respective claims to pleasure"; Robert H. Bork, "Neutral Principles and Some First Amendment Problems," Indiana Law Journal 47 (1971): 9.

96. Theodor W. Adorno and Max Horkheimer, Dialectic of Enlightenment, trans. John Cumming (New York, 1972), 38. As Adorno and Horkheimer observe, "so long as the identity of the user of reason is disregarded," reason acquires an "affinity" with "force" (87).

97. Nonet and Selznick, Law and Society, 29.

98. One alternative conclusion, of course, is that there be no constitutional law at all, but only simple majority rule. The point in text assumes that those propounding the counter-majoritarian difficulty are attempting to offer a characterization of an appropriate, rather than nonexistent, form of constitutional law.

99. For a clear example of this form of argumentation, see Ely, Democracy and Distrust; for a general discussion, see Farber, "Originalism Debate," 1097-1 100.

100. See, e.g., Richard H. Fallon, Jr., "A Constructivist Coherence Theory of Constitutional Interpretation," Harvard Law Review 100 (1987): 1217-23.

101. The phrase is from John Schaar, Legitimacy in the Modern State (New Brunswick, N.J., 1981), 38.

102. Adorno and Horkheimer, Dialectic of Enlightenment, 87. 